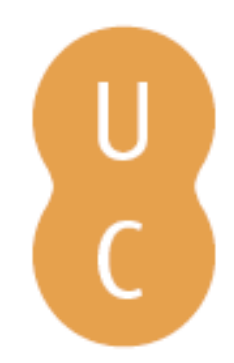

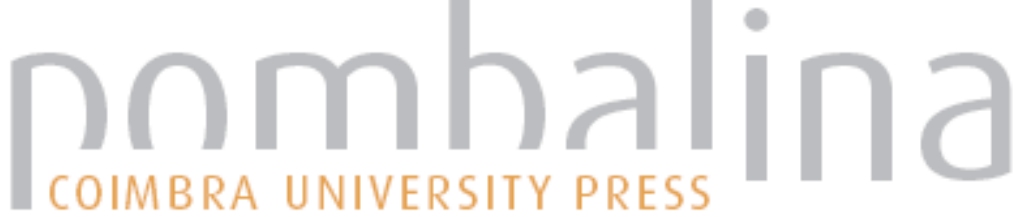

\section{Medeia em Camariñas: Andrés Pociña}

Autor(es): $\quad$ Silva, M. Fátima (trad.)

Publicado por: Imprensa da Universidade de Coimbra

URL

persistente: $\quad$ URI:http://hdl.handle.net/10316.2/44261

DOI: $\quad$ DOl:https://doi.org/10.14195/978-989-26-1526-4_3

Accessed : $\quad$ 26-Apr-2023 01:07:56

A navegação consulta e descarregamento dos títulos inseridos nas Bibliotecas Digitais UC Digitalis, UC Pombalina e UC Impactum, pressupõem a aceitação plena e sem reservas dos Termos e Condições de Uso destas Bibliotecas Digitais, disponíveis em https://digitalis.uc.pt/pt-pt/termos.

Conforme exposto nos referidos Termos e Condições de Uso, o descarregamento de títulos de acesso restrito requer uma licença válida de autorização devendo o utilizador aceder ao(s) documento(s) a partir de um endereço de IP da instituição detentora da supramencionada licença.

Ao utilizador é apenas permitido o descarregamento para uso pessoal, pelo que o emprego do(s) título(s) descarregado(s) para outro fim, designadamente comercial, carece de autorização do respetivo autor ou editor da obra.

Na medida em que todas as obras da UC Digitalis se encontram protegidas pelo Código do Direito de Autor e Direitos Conexos e demais legislação aplicável, toda a cópia, parcial ou total, deste documento, nos casos em que é legalmente admitida, deverá conter ou fazer-se acompanhar por este aviso.

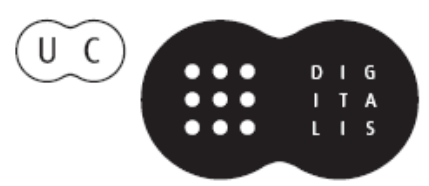




\section{MEDEIA, SAFO, ANTÍGONA}

\section{MITOS ETERNOS, NOVAS LEITURAS}

\section{ANDRÉS POCIÑA}




\section{MEDEIA EM CAMARIÑAS \\ ANDRÉS POCIÑA \\ (Tradução de M. Fátima Silva)}

\section{ELENCO}

Medeia

Uxía

Rosina

Ermitas

Elpidia

Outras mulheres, nunca mais de dez no total.

Fala apenas Medeia, cujo rosto espelha a passagem dos anos e das tristezas, que, apesar de tudo, não conseguiram apagar-lhe a beleza. As outras mimam adequadamente o sentido das palavras da protagonista, de forma discreta. Alguma pode entrar em cena depois de iniciado o monólogo, mas nenhuma sairá enquanto dure a história de Medeia.

Vestem como mulheres de família humilde, do povo, de uma época indeterminada, que pode corresponder a finais do séc. XIX, por exemplo; saias compridas, em todo o caso. O vestido de Medeia vê-se que é velho, mas conserva ainda a aparência de uma categoria muito superior à das outras lavadeiras.

O espaço cénico não exige mais do que um lavadoiro público daqueles que havia nas aldeias, real ou imaginário, com água ou sem ela, embora poder lavar de verdade fosse um recurso de indubitável utilidade. A sua localização numa aldeia da Galiza pode ter-se em conta, mas não é indispensável. Nele lavam as mulheres do elenco, a princípio todas elas claramente afastadas de Medeia.

Tal como o imagina o autor, o monólogo de Medeia tem lugar no Teatro Romano de Mérida. O cenário prolonga-se com uma plataforma, à mesma altura, que ocupa o 
semicírculo da orquestra: aí se monta um lavadoiro público, como os que recordamos da nossa infância e juventude, com entrada e saída de água, que não deixa de correr.

Por trás do lavadoiro, isto é, no espaço da cena, decoração vegetal à base de ramos, pois o lavadoiro encontra-se fora da aldeia, e, como já disse, dentro do possível, estamos na Galiza.

Ao fundo, a fachada do Teatro Romano, tal como ela é, sem iluminação, recorda-nos a Grécia de Eurípides através da Roma de Séneca. A nossa Medeia é uma combinação das duas figuras de ambos os dramaturgos, chegada, no final das suas desditas, a uma aldeia da costa galega, não se sabe bem como.

Esta Medeia é a mulher que se desprende das suas palavras. É mais velha, mas continua a ser Medeia, com a mesma personalidade, a mesma força, a mesma beleza de sempre. Desenhei-a pensando em Nuria Espert (e, um pouco também, imaginando Margarita Xirgu), na Espert da Medeia de Mérida, dirigida por Cacoyannis, no verão de 2001.

MEDEIA - Peço-vos por favor, mulheres de Camariñas, não se ponham a olhar para outro lado, todas de acordo, todas à uma, como sempre fazem quando me vêem chegar. Não venho aqui por vontade própria, podem crer; não há ainda muitos anos tinha eu criadas que me lavavam os vestidos, os engomavam e depois os acariciavam cuidadosamente com o ferro, para deixá-los como novos e tirar-lhes o último vestígio de humidade, depois de borrifá-los com lavanda. Todas ficam mudas mal me vêem aparecer pelo caminho, todas se movem como se picadas por uma mola quando me aproximo da pia, todas me viram as costas, sem responder sequer à minha saudação.

É certo que vocês nunca me acolheram bem, minhas amigas. E no entanto, ao princípio, pelo menos diziam alguma coisa, bom dia, como está a velha, está um dia maravilhoso para secar a roupa; tontarias, se pensarmos bem, mas pelo menos alguma coisa. Em fim de contas, não deixavam de ver em mim uma estrangeira. Acontece sempre assim; recordo que em Corinto diziam: trata bem o estrangeiro, que também tu o serás um dia, longe da tua terra; e no entanto, estão a ver, apesar de casada com um grego, mãe dos filhos de um grego, nunca deixaram de olhar-me como uma estrangeira. Não suportavam ver-me caminhar de cabeça erguida, que os olhasse nos olhos, nem essa minha atitude um pouco altaneira, que me ficou de menina, porque, quer se queira quer não, eu era filha do rei. Convosco passou-se algo semelhante, mulheres de Camariñas: primeiro meias palavras, um comentário, um vago sorriso, e depois o tempo foi passando e vocês foram enchendo com suposições falsas os vazios das vossas perguntas. Vinha um da feira de Vimianzo e trazia uma notícia, que ora combinava, 
ora não, com outras chegadas de Noia, de Laíño, do Porto, ou deus sabe de onde, e vocês vá de contabilizá-la contra mim. Guardavam sempre tudo o que de negativo vos chegava aos ouvidos. Cada dia que passava, as vossas palavras eram menos, e mais o desviar dos vossos olhos.

Não sabem, mulheres, que a sorte é matreira, falsa, traiçoeira: hoje podes estar no alto da montanha, e amanhã precipitas-te pela ladeira e vais parar mais abaixo do que o baixo. Hoje estás na tua terra, e amanhã em terra alheia, e depois de amanhã, se calhar, em outra mais alheia ainda. De tal sorte posso eu ser exemplo. Tempos houve em que a Benita me levava a passear, era eu menina, nos poucos dias em que brilhava o sol naquele frio eterno da Cólquida, a minha terra. Mais tarde, era ela quem me fazia aqueles bonitos penteados que cativavam Jasão, e me entrançava os cabelos com fitas de muitas cores; depois, ali estava a Benita no meu primeiro parto, e no segundo, e era ela quem se ocupava das crianças, quando a pouca alegria de viver me ia deixando sem ânimo. Vejam bem: agora sou eu quem a tem de limpar quando se urina, cada vez com mais frequência, e tenho de vir aqui lavar-lhe as roupas, as dela e as minhas. Que queixa têm vocês de mim? Como vocês se escapam todas para um lado mal me vêem, ponho-me sempre desta outra parte, de onde sai a água, para que não possam dizer que a deixo suja, por causa das calças mijadas da pobre velha. Outras, de entre vós, não merecem tantos olhares, amigas, com a roupa que trazem para lavar. Mas claro, eu sou estrangeira, tudo que faça para não incomodar vos parece pouco.

Que quereis de mim? Aqui estou, só, com a Benita, que é pior do que estar só; aqui me trouxe o destino, depois de percorrer mares e mais mares, terras e mais terras. Nunca vos pedi nada, foi só esse o castigo que nunca tive, o de ter de pedir esmola. Não me meto, seja no que for, nas vossas vidas, nas vossas casas, nas vossas coisas. Então, que mal vos causo eu? Não tenho culpa de que seja salgada a água do mar, pois se assim não fosse era na praia que eu lavaria as roupas, as minhas e as da velha, para vos poupar o terem de agir com tanta cobardia quando me vêem chegar. Com cobardia, sim, não me olhes com essa cara, Uxía. Essa vossa atitude não é digna de mulheres feitas e direitas.

Agora, de há tempos para cá, deu-vos para isso, para juntar num cesto todas as críticas que vos fizeram contra mim, para ir entretecendo umas com as outras todas as maldades que se foram inventando, sem desconfiar nunca do que vos contaram, sem sequer pensarem que podiam ser mentiras ... Hoje deu-vos para isso, e amanhã, quem sabe, pode dar-vos para outra coisa. Oxalá, oxalá, é o que vos digo do coração, mulheres de Camariñas. Porque nem que o fizessem pais, nem mães, nem avôs, nem avós, nem mestres, nem mestras, nem padres, nem freiras: tudo o que vos disseram era mentira, não atino a saber por que razão, mas a verdade é que era mentira atrás de 
mentira, pura calúnia. E no entanto viram-me as costas, e na verdade, ao que parece, ficam na sua. Deu-vos para pensar que tudo é verdade, sem tomarem em conta que tudo foi avantajado ou minimizado, misturado e mitificado, por todos, por todas, e desde sempre ... Vai-se a ver e têm razão, não digo que não. Mas já que se põem assim, já que não estão dispostas a ligar-me, nem sequer a dizer-me 'bom dia, como estás, pararam de supurar as chagas da velha', vou contar-vos a minha história, a verdadeira, não a que vocês teceram, vocês, os vossos pais, os vossos avós, os vossos sacerdotes. Calam-se quando chego, e tu, Marica, paras de cantar, e tu, Rosina, emudeces e deixas de fazer-nos rir com essas fantasias do que fazes com o teu noivo, no feno do alpendre ... Portanto, hoje toca-me falar de mim. Oiçam um pouco, amigas, e depois falamos de verdades e mentiras.

Para começar, nunca soube quem inventou essa tontice do pêlo do carneiro, essa história do velo de ouro, que pode ser muito bonita, não digo que não, mas que é uma verdadeira história de crianças. Quando Jasão veio para a Cólquida, sabia muito bem ao que vinha, porque tinha começado a preparar a viagem de há muito tempo antes. Não vou fingir agora que não lhe tivesse posto um pouco de aventura, o desejo de conhecer as terras do norte, tão afastadas e misteriosas; de facto, ele sempre foi muito grego, e aos gregos, mais do que às gregas, sempre lhes agradou viajar, ir para longe, correr mundo, conhecer outros horizontes. Nisso parecem-se muito com a gente aqui da vossa terra. E Jasão não era exceção, como podem imaginar. Mas quando veio para a Cólquida a sua intenção era a que quase sempre incita os homens a viajar: ou por negócios, ou para fazer guerra. A nós, as mulheres, movem-nos outras razões, mais rebuscadas: a principal, julgo eu, é a curiosidade, o desejo de ver, de descobrir, de conhecer coisas novas, pessoas novas, com a esperança de que sejam diferentes. Jasão, não vou dizer-vos que tenha ido até lá para guerrear com o meu pai, nunca foi tipo para grandes façanhas. Não, não: cobarde não era, não foi intenção minha dizer tal coisa, amigas; mas lutador também não. Necessitava sempre que o puxassem, que o empurrassem, e gostava de deixar-se levar.

É o que vos digo, não sei quem, diabos, foi inventar essa treta do velo de ouro. Se virem bem, a trama é bonita, mas quem pode acreditar em semelhante fantasia? A verdade é outra, muito diferente: na Cólquida tínhamos uma raça de ovelhas que não havia nas terras do Sul. Vocês nunca foram à Cólquida, nem sequer à Grécia, e de aqui, de tão longe, não é fácil imaginar como ela é. Não digo que não tenha um encanto especial, mas o clima é terrível, sobretudo durante o inverno: chega muito cedo, já em Setembro, e no mês dos Santos não se suporta aquele frio, aqueles nevões que não passam nunca, aquela humidade que se nos vai metendo à traição nos ossos. 
A paisagem é muito bonita, lembra muito esta vossa daqui, mas tantas montanhas e tamanho inverno lá dão cabo seja de quem for ...

Além disso acontece que sempre fomos um povo muito atrasado. Não por causa do meu pai, que ele fez o que pôde, herdou o que herdou, e atrás de si deixou o que deixou. Não é como aqui, não há comparação possível, onde, que mais não seja pelo abrigo da ria, não deixam de chegar barcos, e com o negócio das rendas vocês, mulheres, vão aos mercados, vêem outras gentes, e com elas outros usos. Lá, à Cólquida, não chega ninguém, sobretudo no inverno; mas mesmo no verão aquele mar é perigosíssimo, e quando por fim se chega a terra só se encontra montanhas e mais montanhas. Por isso sempre vivemos da terra, uma colheitazita de nada cada verão, porque mal começa o outono já tudo congela; e sobretudo do gado. Cabras e ovelhas principalmente. Era assim o país em que eu vivia, já podem imaginar de que maneira: muito filha do rei, é certo, mas do rei de um povo de pastores.

Quando olho para trás, penso que me falta algo, sim: deve ser isso a que vocês chamam saudades. Talvez. Mas estou segura de que não sinto a falta daqueles invernos, daquele frio, daquele aborrecimento, daqueles homens que só queriam deitar-se em cima de uma mulher e falar das ovelhas, com aquele cheiro ácido que traziam da montanha e que lhes não deixava o corpo. Já vejo que vocês me não compreendem. Mas diz-me tu, Uxía, que vida podia eu ter ali, deixem-me que vos diga, por muito filha do rei que fosse? Assim iam as coisas, tinha eu acabado de fazer dezassete anos, quando chegou Jasão.

Não vinha buscar nenhum velo de ouro, repito-vos que nunca tal coisa existiu, nem na Cólquida nem em parte alguma. O caso era que o meu pai tinha trazido de muito longe, das terras acima do Danúbio, parece-me (era eu então uma criança de apenas três ou quatro anos), umas ovelhas raras, maiores, meio aloiradas, muito bonitas, que davam uma lã muito boa, espessa, macia, mais comprida do que a das ovelhas gregas. Pode parecer-vos mentira, mas foi apenas por isso, nem mais nem menos, que ele alugou o barco e realizou uma tal viagem: tudo para ver se o meu pai the vendia alguns pares de ovelhas, ou mesmo só um carneiro para o cruzar com as ovelhas de Iolco, a terra de Jasão, que eu nunca as cheguei a ver, mas que se imagina que deviam ser bastante medíocres. Tudo o mais é mentira: nem nau Argo, nem guerreiros formosos das melhores famílias na tripulação, nem herói caído do céu à procura do nunca visto velo da lenda. Vejam bem, para nos deixarmos de fantasias: Jasão veio à Cólquida mais ou menos como qualquer uma de vocês vai ao mercado, só que vocês vão para vender rendas, e ele veio para comprar ovelhas. A única diferença reside nas personagens: no nosso caso, as gentes da Cólquida, tontas, patetas, com tão poucos conhecimentos e com tão pouco mundo percorrido, e ele, Jasão, com aquela educação que tinha, tão diferente, tão nunca vista. E também, não encontro motivo para o negar, com aquela sua indescritível beleza. 
Jasão era, nesse tempo, um homem de uns trinta anos, esbelto, muito esbelto: era alto, robusto, sem ser gordo, que é outra coisa; tinha umas pernas fantásticas, compridas, bem torneadas, e um peito poderoso, em que cada músculo sobressaía com um relevo próprio; o corpo era o de um autêntico ginasta. Podem bem imaginar o trabalho que dá conseguir um corpo assim. E depois tinha aquela cara tão formosa, sobretudo os lábios que dava vontade de beijá-los, e os olhos verdes, da cor das azeitonas quando começam a amadurecer, justamente antes de se fazerem violeta com a luz do outono. Malditos olhos de Jasão! Quando nos olhava, não se sabia o que fazer, porque nos vinha um calafrio que percorria o corpo inteiro, e se tinha medo que ele percebesse o que nos ia lá dentro. Depois tinha aqueles caracóis loiros, sempre tão limpos, tão brilhantes, tão bem penteados, que talvez fosse o que mais o distinguia dos homens da Cólquida, sempre tão desgrenhados e com pinta de porcos ... Com pinta, e na maior parte das vezes também com o jeito, o que ainda era pior.

É assim que o recordo, da primeira vez que o vi, quando veio ao palácio apresentar os seus respeitos ao meu pai, o rei. Eu estava lá, entre a família real, ao lado da minha irmãzita, e ele chamou-me muito a atenção, para quê negá-lo. Vinha muito elegante, amigas, escoltado por uma dezena de homens com bom porte, quase todos jovens, falando com aquele acento estrangeiro, tão fino, tão distinto, tão diferente do nosso. Eu tinha, já vos digo, dezassete anos, e penso que forçosamente tinha de impressionar-me. Mas foi tudo, nem mais nem menos. De forma que não é correta toda essa série de tontarias que, mais tarde, inventou o cego de Rodes - que vocês não conhecem -, um como os que aqui cantam nas feiras. Mas o tal sujeito de Rodes é um troca-tintas, que já anda bêbedo mal que se levanta, e não pára de inventar histórias e de sacar contos de tudo o que mexe. Sobre mim deu em dizer que, quando vi Jasão, o coração me saía do peito, os olhos se me enevoavam e as pernas me falhavam. Tudo tontarias. E mentira. Como também essa peta que arranjou das doze criadas: é preciso pouco senso para dizer semelhante bojarda. Como é que ia ter doze criadas uma princesa da Cólquida? Tinha três, o que já me não parece pouco, sobretudo se me vir como agora me vejo, eu mesma criada da única que me resta. Sem dúvida que me entristece recordar o que lhes aconteceu pouco tempo depois: quando fugi da minha terra, duas delas estavam grávidas, não sei de quem, mas seguramente de algum dos companheiros de Jasão; a terceira, uma morenita muito jovem, que sem dúvida nos tinha costado bom dinheiro, muito linda e graciosa, tinha-se enforcado dias antes, atirando-se da torre alta do palácio com uma corda de nó corrediço ao pescoço; nunca soube por que motivo o fez, embora possa imaginá-lo.

Tudo, tudo, tudo, o que o cego ia contando pelas feiras e mercados era um punhado de mentiras. A mim, Jasão agradou-me desde o primeiro momento, é verdade, mas como nos pode agradar um homem esbelto, ou um vestido, ou a ria e a hora em que o sol mergulha no horizonte. Que tenha ficado louca por ele quando o vi, nem pouco 
menos. Andava muito ocupada naqueles tempos com um companheiro do meu irmão Apsirto, que não queria saber de mim, mas que, já de criança, me deixava brincar com eles os dois, para depois se aproveitar de mim quando conseguia pôr a andar o Apsirto, inventando algum pretexto para ficar a sós comigo.

Palavra que foi assim, Marica; podes crer. A história com Jasão não tem nada que ver com o que imaginou o cego de Rodes, nem com o que divulgaram por aí dezenas de bocas mentirosas. É isso precisamente o que mais me aborrece, porque vejamos: porque teria de ser eu a enamorar-me à primeira vista de Jasão, e não ele de mim? Vocês, agora, vêem-me assim, como estou, depois de tantas desgraças, com dois partos pelo meio, com tantos meses passados por mares e por caminhos até chegar a esta terra, e, mesmo assim, não vão negar que ainda sou um pedaço de mulher. Imaginem-me então com dezassete anos, com estas tetas bem postas no sítio, com esta cintura de vespa que chamava a atenção, com estas pernas que ainda agora tenho, olhem, olhem, toquem se quiserem, e pensem como seria tudo isto antes de ter parido e amamentado, que é o que mais nos estraga, a nós as mulheres. Pois vejam bem, a nenhum dos que sobre mim inventaram calúnias lhe passou sequer pela cabeça a possibilidade de que fosse ele o primeiro a enamorar-se. O que me mata é ter de dar-lhes alguma razão, porque, mesmo que não tenha sido como costuma contar-se, e mesmo que nunca me tenha enamorado por ele a sério, está na cara que, por ele, cheguei a perder a cabeça. E a verdade inquestionável é que Jasão, por seu lado, nunca gostou de mim, nem um pouco que seja.

Vou contar-vos a história, pois já vejo que vos interessa. Jasão, como é natural, instalou-se no palácio do meu pai com todos aqueles preguiçosos que tinha trazido com ele no barco. Não sei se vocês sabem como funciona na Grécia a questão da hospitalidade: na Cólquida é exatamente o mesmo. Outra invenção dos homens, para estarem cómodos quando viajam, seja onde for que vão, para terem cama feita, mesa posta, e criadas jovens para desafogar-se: hoje, tu na minha casa, amanhã eu na tua, este é um costume já muito antigo, uma honra para o povo grego. Naturalmente, honroso para os homens do povo grego, porque, ao que se diz, para as mulheres ... Mas deixemos essa história para outra ocasião. O rei deu-lhes hospitalidade, todo o tempo que quiseram, e assim alguns, quando fugimos da Cólquida, voltaram que nem porcos cebados de tanto que tinham emborcado. Já para não falar de como andavam pelos corredores do palácio, ou pelos passeios do jardim, ou pelo caminho da fonte das três bicas, sempre à espreita, que nem cães com cio, atrás das criadas que ali iam buscar água de cântaros à cabeça, com aquele sorriso e aquela graça no andar que sempre tiveram as moças da Cólquida.

Mas o meu pai era homem de uma só palavra, e ainda que se fizesse cego e surdo para outras coisas, a Jasão desenganou-o logo no primeiro jantar: o palácio estava à sua disposição - disse-lhe -, cama limpa e mesa farta, por todo o tempo que quisesse, mas 
que lhe não passasse pela cabeça levar nem uma só ovelha das suas. Não o incomodava reconhecer que eram a jóia maior do seu reino. Se tivessem tido a lã de oiro, como diz esse conto do velo que inventaram mais tarde, não lhes daria mais valor. Eram o seu orgulho. Nem o filho, e muito menos a mulher e as filhas, representavam tanto para ele. O maior orgulho do rei da Cólquida era uma raça de ovelhas. Desagradável! Pois é assim mesmo, Ermitas, tal como vos estou a contar, sem tirar nem pôr. Que forma mais estranha de pensar têm os homens, também os daqui, nem é preciso dizê-lo.

E foi assim que entendeu tramar o que tramou. Imaginou com certeza que, se não conseguia convencer o rei, o melhor era encantar a filha, ou, para dizê-lo de outro modo, enganar Medeia para enganar o pai. Enfurece-me ter de reconhecê-lo, mas o certo é que lhe não deu muito trabalho: Jasão tinha uma experiência que a mim me faltava; havia, além disso, não só aqueles olhos, aqueles lábios, aquelas mãos, aquele peito, aquele volume entre as pernas ... como também as palavras que me dizia. Os gregos sempre tiveram essa vantagem sobre os outros povos: são donos e senhores da palavra, tanto para dizer verdades como para maquinar mentiras, para elogiar ou para insultar. Sabem perfeitamente que podem levar a melhor sobre nós, as gentes a quem chamam bárbaras, simplesmente porque não tivemos escola, nem leituras, nem poetas, e não sabemos usar a língua como eles. Nenhum homem nem mulher da Cólquida se prestaria nunca a inventar todas aquelas coisas que inventaram os companheiros de viagem de Jasão, todas aquelas aventuras, riscos e perigos que diziam que ele passou para roubar o famoso velo ao bárbaro do meu pai. E por acréscimo metiam-me a mim, umas vezes como uma bruxa, outras como uma tonta, preparando-lhe unguentos e cozimentos para o ajudar, segundo alguns só a troco de uma promessa de casamento...

Quanta mentira junta, minhas amigas! Sabia ele muito bem que não foi assim, que era ele que me não deixava em paz, que vinha atrás de mim como um cachorro faminto, que me prometia este mundo e o outro, palácios imensos que dizia ter na longínqua Iolco, onde nunca havia estado nenhum dos meus conhecidos; e fazia-me sonhar com uma casa própria, minha, com uma família, filhos, e amor, muito amor, um amor grande, forte, eterno. Um amor que dizia que me tinha desde a primeira vez que me tinha visto, tal como se o próprio Eros lho tivesse metido no corpo. Pobre de mim! E eu ali, feita uma tonta varrida, a ouvir aquela torrente de palavras, e a perguntar-me quem seria esse Eros (o que ele se não há-de ter rido de mim!), porque na Cólquida os deuses eram uma coisa mais séria, e jamais tínhamos ouvido falar de um semelhante. Às vezes penso e volto a pensar no muito que se há-de ter rido à minha custa. Não me admiraria que, depois de deixar-me à noite, farto de me cavalgar debaixo da figueira grande, fosse despertar os companheiros para lhes contar como se deixava manobrar Medeia, a idiota da filha do rei, tão tontinha a pobre que até nunca antes tinha ouvido falar do deus Eros. 
Bem vêem, amigas. Conto-vos tudo isto como se o estivesse a viver de novo. Recordei tantas vezes o que se passou naquele tempo! E no entanto, não pensem que me enamorei de Jasão. Repito-vos que isto foi sempre o que mais me aborreceu, que todos os que falam de mim, até vocês mesmas, tenho a certeza - não me olhes assim, Rosina, pois bem imagino o que vocês dirão quando não estou presente -, de certeza que me imaginam loucamente apaixonada. Há um sujeito que não recordo como se chama, um charlatão de feira, mas que pelos vistos conta coisas com imensa graça, escolhendo muito bem as palavras, bem ao contrário do que eu faço, que, ao que me disseram, inventou a meu respeito coisas muito divertidas: parece que me imagina a correr sempre de um lado para o outro montada em dragões - estão a ver que história-, a misturar ervas e outras mezinhas para rejuvenescer os velhos! Isso queria eu, oh se queria! Porque se eu fosse uma bruxa como dizem, se tivesse tantos poderes e tanta sabedoria como imaginam, já me teria virado de outra forma em Camariñas, havia de arranjar maneira de não ter de viver nessa pobre choupana, cheia de goteiras que não nos dão descanso mal começam as chuvas, e não teria de levar o meu tempo a dar cabo da vista para não confundir os pauzinhos ao tecer a renda.

Bruxa ou não - que vos juro que não existe tal coisa - o certo e verdadeiro é que me deixou fascinada a beleza de Jasão, a sua elegância, tudo isso que já vos contei; em consequência, como era muito jovem, fui ficando apanhada na sua rede. Mas há também quem diga que, para mim, Jasão representava a oportunidade de abalar da Cólquida, de ver outras gentes, outros países, outras cidades. Aí, pesa muito ter de o reconhecer, acertou no alvo, fosse quem fosse. A mim o mundo em que os homens se parecessem com Jasão, se vestissem como ele, falassem com as mesmas palavras, parecia-me que tinha de ser formoso, divino. Na terra do meu pai não me esperava outro futuro que não fosse casar-me com um fazendeiro mais ou menos bruto, que viria ao fim da tarde cansado de andar pelos montes com o gado, que jantaria com certeza sem se lavar, que iria para a cama e, sem dar palavra, me faria quatro, seis, oito, dez filhos, até me converter numa velha antes do tempo, à força de parir e de enterrar meninos; quando esse momento chegasse, preferiria deitar-se com as criadas jovens. Jasão podia livrar-me dessa perspetiva, e foi isso o que eu descobri nele. Mas enamorada, o que se diz enamorada, isso de certeza que nunca estive. Nunca, filha, posso garantir-te que nunca. Gostar de um homem, ou mesmo ir para a cama com ele, ou até, se apertas comigo, gozar com ele entre as nádegas, não é a mesma coisa que estar enamorada. Isso deve ser outra coisa, não sei bem o quê, mas uma coisa diferente.

E ainda vos digo mais, mulheres. É que também nunca gozei com ele na cama. Coisas destas, eu sei, não são para contar, mas estou farta de que inventem sobre mim histórias falsas. Como eu reconheço e não me canso de repetir que era um homem 
inteiro, desejável, formoso, pode parecer que, enamorada ou não, gozava em deitar-me com ele. Isso para os homens é muito claro: pensam que nós, as mulheres, temos de ter prazer sempre debaixo deles, porque são muito homens, muito machos, e andam por esse mundo a distribuir benesses. Mas eu juro-vos pela memória dos meus filhos: anos e anos me deitei com ele e nunca tive um orgasmo com Jasão. De modo que, quando contam que tudo o que se passou no fim da nossa relação foi culpa dos ciúmes que Jasão me fazia com a tonta da filha do rei Creonte, tudo não passa de uma invenção idiota; quando tudo aconteceu, havia já muito tempo que eu tinha perdido toda a esperança de ter prazer com ele na cama.

Para Jasão o amor era algo assim como lavar a cara de manhã, ou como comer, ou como urinar; era uma pura relação física, ir para a cama, pôr-se em cima de mim, abrir-me as pernas, penetrar-me, e é tudo, um pouco de mete-tira ... e deixar-me frustrada e insatisfeita quando começavam a despertar-se-me os sentidos. E eles sabem - bom, decerto que não, mas é a mesma coisa - que nós as mulheres precisamos de outra coisa, não vos parece? Claro que sim. Que não nos adianta nem atrasa que nos tratem como galinhas, que não somos animais de reprodução. Jasão nunca pensou nisso, creio que nem comigo nem com qualquer mulher. Nunca o soube nem houve forma de o fazer aprender. Tinha essa suficiência de galo, de macho, e julgava que ser homem é saber como se fazem filhos, passando uns momentos fantásticos, mas ele e só ele. Foi assim que se portou, e tivemos dois filhos, como sabeis todas. Mas nunca conseguiu levar-me a esse paraíso onde nós, as mulheres, gostaríamos que nos levassem os homens, quando, na cama, nos apertam com os seus músculos e, triunfantes, nos entram no corpo.

Mas fiquemos por aqui, que ainda vos podia dar muito mais detalhes. Não, não, não me peças que fale, Rosina. Agora já não me interessa, e podem crer: se vos contei tudo isto não é porque goste de contá-lo, nem de deixá-lo numa posição difícil. O que me aborrece é que digam sempre que foi como não foi. E outro tanto se passou com a fuga da Cólquida, com Jasão e os companheiros, que sempre a contam como uma façanha: foi simplesmente o roubo de uma ovelha e de um carneiro, de noite, às escondidas, com muito cuidado para que os mastins do palácio não começassem a ladrar. Com a particularidade de que, para o que desse e viesse, Jasão e os outros estavam no barco, preparados, com os cordames soltos, prontinhos para fugir se nos descobrissem. Na verdade, quem roubou a ovelha e o carneiro, nos estábulos do nosso pai, fomos eu e o meu irmão Apsirto; ele e eu tivemos de levar os dois animaizitos até ao porto, cuidando de que não fizessem barulho; no meio disto tudo, Apsirto ia, na obscuridade, tão morto de medo que deixou escapar a ovelha que era o que ele levava, enquanto eu arrastava o carneiro, muito mais difícil de dominar. Foi esta a forma como Jasão fugiu 
da Cólquida, e foi assim que Medeia fugiu do reino do seu pai: de noite, às escondidas, como fazem os fugitivos no monte, roubando um carneiro ao rei para o cruzar com as ovelhas de Iolco. Já vêem, amigas, que lenda mais gloriosa!

Por falar de Apsirto, aí sim, é certo que deram asas à imaginação. Não sei quem tramou semelhante calúnia, mas inventaram que o meu pai, quando de manhãzinha descobriu que tinham fugido Jasão e os seus homens, e com eles Apsirto e eu, e para mais levando connosco um carneiro, o famoso velo de ouro ao que diziam, partiu de barco em nossa perseguição. Então - vejam bem o que vos digo -, dizem que eu, Medeia, um monstro malvado, Medeia, sim, assim mesmo, com as seis letras do meu nome, matei o meu irmão a bordo, e me pus na coberta do barco a cortar-lhe o corpo em pedaços que atirava ao mar, para que o meu pai tivesse de ir parando a recolhê-los. Que imaginação têm os Gregos! ... E que mau caráter! Para demonstrar que tudo isso é mentira chega e sobra que diga que o meu pai nunca na vida teve barcos, como bem sabem as gentes da Cólquida: sempre viveu no campo, sobretudo do gado, das ovelhas, das cabras, de oito ou nove vacas, de uns vinte porcos, e aí se lhe acaba a propriedade. Os gregos são muito hábeis para algumas coisas, mas noutras a imaginação leva-lhes a melhor.

E, já agora, oiçam a verdade, mulheres. A primeira coisa que não passa de uma mentira é que eu levasse Apsirto à força. Sempre quis ao meu irmão com loucura, já desde crianças, porque gostava mais de brincar com ele do que com a minha irmã. Calcíope aborrecia-me muito, sempre com as bonecas, a vesti-las primeiro para a seguir as despir, todo o dia a fazer comidinhas a fingir, a pintar a cara com as amoras das silvas, ou com grãos maduros de uvas garnacha ou com bagas de outros arbustos, para se enfeitar diante do espelho. A mim aquilo aborrecia-me supinamente, e andava sempre com o Apsirto, que na verdade era só dois anos mais novo do que eu, e de forma alguma um menino pequeno quando fugimos da Cólquida; com ele, e com mais dois ou três miúdos amigos dele, passei os momentos mais bonitos da minha infância. Gostávamos muito um do outro, razão mais do que suficiente para que me não fizesse aquilo que depois me fez, ele a mim e não eu a ele. Digam-me, mulheres, como ia eu, ou qualquer pessoa no seu perfeito juízo, cortar um irmão em pedacinhos?

Foi o Apsirto quem me disse um dia que queria fugir da Cólquida, com Jasão e comigo. A princípio deu-me que pensar, porque eu nunca lhe tinha contado que projetávamos escapar-nos uma noite da maneira que vos contei; ele não me explicou como tinha ficado a saber, e eu também lhe não perguntei. Tarde demais vim a sabê-lo, e de modo cruel: numa noite em que já estávamos longe da Cólquida, fundeámos no Bósforo para dormir. De repente, despertei com uma sensação estranha, uma angústia, um não sei quê; a primeira coisa que me surpreendeu foi que Jasão não estava ao meu lado, 
como quando adormeci, que naquele tempo ainda dormíamos juntos. Uma lua cheia, imensa, iluminava o mar como se fosse de dia: era um espetáculo divino, como eu nunca tinha visto; o mar estava quieto, caladinho, e com os raios da lua a refletirem-se nas águas parecia uma enorme mesa de mármore cristalino. Estava eu absorta com aquele espetáculo - dádiva de deuses -, quando de repente, a muito poucos passos de mim, oiço uns soluços abafados, uns gemidos, uns risinhos, e descubro na obscuridade da coberta os corpos completamente nus de Jasão e de Apsirto, enrolados um no outro, com um movimento às vezes lento, compassado, outras apressado, violento, fácil de interpretar. Não é coisa para fazer rir, mulheres. Porque não se põem vocês na minha situação, só por um momento, diante daquela cena belíssima, aqueles dois corpos lindos gozando um prazer sem limites, embalados pelo mar e iluminados pela lua, que mal me deixavam perceber aquela puntada no peito e, nos olhos, as lágrimas?

Pela manhã, obriguei-o a desembarcar, e ali ficou o Apsirto, na margem do Bósforo. Talvez vocês pensem que também devia ter deixado com ele Jasão, e eu concordo; mas havia já quatro meses completos que eu estava grávida do primeiro dos meus filhos e não tive a coragem necessária para ficar sozinha, rumo a terras desconhecidas. Além disso, o que ia ser do barco sem ele? O meu atrevimento não foi além de ameaçá-lo de revelar o que tinha visto à luz da lua, de contar tudo a todos os seus companheiros, se me não obedecesse e obrigasse Apsirto a descer ali mesmo. Porque a sua primeira reação foi resistir a abandoná-lo. Muitas vezes me tenho arrependido daquela decisão: era eu quem devia ter ficado nas ribas do Bósforo.

O que se passou depois seguramente vocês o sabem melhor, porque é o que sempre se conta nos banquetes e nas festas, nas cenas das matanças, nas noites de desfolhar e de debulhar o milho, nas festas da colheita da castanha, e até - que vergonha dizê-lo - às vezes nos velórios. Mas acontece sempre como com os contos, vai-se acrescentando e tirando coisas, porque, já se sabe, se não se lhes acrescenta muita fantasia não interessam a ninguém. Conheço eu bem algumas pessoas, não, alguns homens, com nome e apelido, que inventaram coisas para me difamar. Há um a que não perdoo que me tratasse como uma bárbara, um que inventou toda essa história de que matei a filha do rei Creonte. Estou certa de que vocês conhecem a história. Vamos lá, mulher, não me venhas dizer que nunca a ouviste. A sério que não? Pois então, vê lá: o estupor do fulano vá de inventar que, para me vingar dela, porque me roubava o marido, lhe mandei não sei se um véu de renda, ou uma coroa, não recordo bem o quê, algo com um feitiço; e aquela tontinha -que lá tonta era ela de verdade! -, foi pô-los na cabeça e converteu-se em chamas que a queimaram viva; e não só ela, como também o pai, que veio a correr socorrê-la. Tudo pura mentira! A mim não me agrada esse talento 
fantástico que têm os homens, palavra! São capazes de inventar as coisas mais estapafúrdias deste mundo e do outro para explicar as mais simples. Sem qualquer senso comum! Que raiva quando o sabão se escapa das mãos e vai parar ao fundo da água! Deixa para lá, Sabela. Fica com esse meu pano, se quiseres, que a mim não me faz falta.

Pois vejam bem, a filha de Creonte era uma imbecil e uma presumida, e também bastante quente sem dúvida. Bastava pôr-se-lhe um homem na frente, que a primeira coisa que fazia era reparar se lhe avultava algo naquele sítio que todas sabemos. Olhava para o cu dos tipos e ficava de olhos em alvo. Não tinha mais do que serrim na cabeça. Mas quero que tenham por certas duas coisas: a primeira é que, a mim, nunca me preocupou o mínimo que fosse. Quando Jasão disse que se casava com ela, já eu levava anos - vejam bem - anos a fio sem ir para a cama com ele. Depois daquela noite do Bósforo, nunca mais fui capaz de suportá-lo em cima de mim sem me lembrar do meu irmão, de quem com certeza nunca mais tive notícia, e nem mesmo sei se está vivo ou morto. De modo que, a mim, que raio me importava se ele se casava ou não com ela, e muito menos tive ciúmes, como disseram alguns. Se alguma coisa sentia por ela era pena, por vê-la cair no mesmo engano em que eu tinha caído anos antes: a Jasão, a única coisa que nela o interessava, era casar-se com a filha do rei de Corinto. A segunda é que fiquem certas de que, por muito parva que fosse, não podia sê-lo ao ponto de aceitar uma prenda que lhe viesse de mim, que, pelo menos publicamente, era a sua grande inimiga. Já se vê que são invenções de homens, que deliram em imaginar mulheres completamente desprovidas de senso comum. Penso que ficariam felizes se fôssemos todas animais irracionais, isso sim, sem deixarmos de ter aquela coisa que temos entre as pernas.

Disse-me uma amiga que até bem longe, no estrangeiro, inventaram histórias a meu respeito. Claro que a mim não me importa nada, e penso que nem merece a pena falar delas. Parece que há um louco, que para divertir outro ainda mais louco do que ele, mas que tem dinheiro a rodos e mesa farta, conta com muitos requintes que tudo o que fiz ou deixei de fazer foi por ser uma histérica enamorada. No fundo tanto me faz, porque essa gentinha me está bem longe, e agora mais do que nunca. O curioso é que foram sempre homens quem inventou essas loucuras, e outras muitas que eu calo. Uma mulher que contasse a minha história certamente não diria semelhantes coisas; mas claro, já se sabe que as mulheres não riscam nada.

O que mais me aborrece é que possam inventar toda uma história a meu respeito sem terem compreendido nada, chegando até a dizer que eu estava loucamente enamorada de Jasão, não digo já quando o conheci e fugi com ele do palácio do meu pai, mas mesmo anos depois, quando fomos bater com os ossos na malfadada Corinto. Nem antes, nem durante, nem depois amei Jasão, minhas amigas de Camariñas (deixem que por uma vez vos trate assim, já que me estão a ouvir). Pari dois filhos, é certo, e muito formosos: 
ao primeiro pus o nome de Éson, como o pai de Jasão, porque fiquem a saber que, na Grécia, o primeiro filho tem de ter o mesmo nome do avô paterno; era loiro, de olhos verdes como as azeitonas no fim do verão, e tinha uns lábios finos, em forma de coração. Ao segundo chamei Eetes, como o meu pai, ainda que Jasão se risse às gargalhadas, dizendo que era um nome bárbaro e que não lhe ia valer senão zombarias quando fosse crescido. Eu fiz de conta. Eetes era moreno, de pele escura, de olhos pretíssimos, assim como estes meus, vejam. Não tinha nada do pai, que foi o castigo que lhe impus porque mo fez à traição, num dia de festa em que tínhamos bebido bastante, quase à força . Como pode passar pela cabeça de alguém que eu estivesse apaixonada por ele?

Nem como amante, nem como marido, nem como pai, nem como homem, Jasão jamais valeu alguma coisa. E mesmo assim podem ver um montão de homens a defendê-lo, a ocultar-lhe a falsidade, a cobardia, a insensibilidade. Até um herói chegaram a fazer dele, como se fosse um novo Aquiles, um Agamémnon, um Ulisses. Não é que me aborreça que gostem tanto dele, porque são muito livres de inventar à vontade. Por mim até podiam canonizar a puta que os pariu se lhes desse na gana. O que me dá pena é ter chegado até aqui, a esta idade, sem encontrar ninguém que tenha compreendido o âmago dos meus sentimentos, os motivos da minha existência, encontrando em contrapartida uma série de homens a tentarem cobrir de insultos uma mulher, bem desditosa por certo, que teve a desdita de chamar-se Medeia.

Vejam bem que tarde de sol para pôr a roupa a corar! E eu aqui a dar à língua e a fazer-vos perder tempo ... Mas como ia dizendo. Talvez até tenham razão, não há que negá-lo, porque são muitos e, salvo em alguns pormenores mínimos, coincidem todos. Mas se, por casualidade, acontecer que algum deles vos venha contar histórias a meu respeito, escutem bem o que vos digo, ao menos vocês, mulheres de Camariñas, e depois voltem-me de novo as costas se assim vos parecer.

Fiquem a saber que fui eu quem pariu os meus dois pequeninos. Éson, o loiro, e Eetes, o moreno. Fui eu quem os trouxe nove meses na barriga, a cada um deles, sem ponta de prazer no momento de engendrá-los, mas com uma alegria infinita quando senti os seus primeiros movimentos dentro de mim. Fui eu quem os amamentou, sem deixar sequer que se aproximassem amas de peito, como pretendia o pai. Fui eu quem lhes limpou os rabinhos de nácar, e os lavou até que aprendessem a cuidar-se a si mesmos. Fui eu quem aprendeu a tecer roupitas para eles, coisa que nunca antes me tinha sequer passado pela cabeça. Fui eu quem os ensinou a andar, a falar, a rir, a brincar atirando pedrinhas nas águas azuis do canal, aquele famoso canal de Corinto, que sempre recordo aqui quando o sol se reflete na ria. Fui eu quem lhes meteu na alma o gozo das cores do céu ao anoitecer, quem os ensinou a perceber os encantos das terras, das ilhas, dos rios e dos mares da Grécia, presente dos deuses aos mortais. Não foi Jasão, nem muito menos o tirano Creonte, quem fez qualquer destas coisas e outras que guardo no coração. 
Quis aos meus filhos como qualquer de vocês, as que são mães, querem aos vossos. Por eles suportava tudo, para que crescessem ali, em Corinto, com a educação dos homens gregos, que, apesar de tudo o que vos disse deles, era muito melhor que a daquelas bestas da Cólquida que rodearam a minha infância. Por eles continuava a viver com Jasão, salvando as aparências, vendo-o, durante o dia, o menos possível, e de noite, na cama, nem pensar. Para eles queria um mundo diferente, um modo de pensar diferente, estremecendo à simples ideia de que um dia pudessem vir a ser outros Jasões. E nas longas noites de inverno, sentada ao calor do fogo, sonhava acordada com vê-los criados, com casá-los apaixonados de verdade, com esperar que enchessem as suas casas de meninos e meninas ... E assim, ir passando os anos pouco a pouco, tranquila, ditosa, sabendo que eles estariam ali para ajudar-me na velhice, para me fechar os olhos quando o Fado o entendesse.

Foram sonhos de muitos anos, o único consolo que me restava quando Jasão me tirou todas as esperanças que todas nós, mulheres, pomos ao pensar num homem, numa casa, numa família. Vocês sabem bem do que falo, amigas. E de repente, chegam-me todos com uma notícia inconcebível: que Jasão se vai casar com a filha de Creonte, e que eu tenho de me ir de Corinto, enquanto os meus filhos, Éson, o loiro, e Eetes, o moreno, deviam ficar com o pai, que deles se ocuparia a sua nova mulher, a tonta da filha de Creonte, que estariam mais seguros no palácio do rei de Corinto, que ninguém podia cuidar deles melhor do que o pai, Jasão ...

Só que eles eram meus, mulheres de Camariñas. Tinha sido eu quem os tinha engendrado, quem os tinha parido, quem os tinha amamentado, quem os tinha criado, e tudo com o mais intenso amor de mãe. Se não iam ser meus, não seriam de mais ninguém. E matei-os.

Fica congelada a imagem de Medeia, um rosto de dor indizível, o olhar cravado no infinito. Em volta dela, as mulheres de Camariñas formam um retábulo trágico no lavadoiro, com os olhares perdidos, partícipes da dor da protagonista.

Vinda não sei de onde, uma voz de mulher, forte e desgarrada, imensamente triste, canta sem acompanhamento as duas primeiras estrofes do 'Epitáfio' de Yannis Ritsos, com música de Mikis Theodorakis.

Filho meu, entranhas das minhas entranhas, coraçãozinho do meu coração, passarito do meu pobre pátio, flor do meu deserto, como fecharam os teus olhinhos, e não vês que choro, e não te agitas, não entendes as amarguras que te estou dizendo?

Com a última palavra da canção, obscurece-se a cena de repente e por completo. 